\title{
TINJAUAN TEOLOGIS-DOGMATIS TENTANG SAKRAMEN DALAM PELAYANAN GEREJAWI
}

\author{
Dominggus E. Naat \\ Sekolah Tinggi AlkitabTiranus \\ Jl. Cihanjuang Km. 5,2, Cihanjuang, Parongpong, Bandung Barat, Jawa Barat \\ dominggus_naat@yahoo.com
}

\begin{abstract}
ABSTRAK: Sakramen adalah suatu ritus Kristen yang ditetapkan dan dilaksanakan oleh gereja sejak berabad-abad yang lalu. Terdapat beragam pandangan tentang makna sakramen dalam gereja. Ada gereja yang menganggap sakramen sebagai tanda yang kelihatan, atau hanyalah tanda lahiriah di mana Tuhan menyatakan anugerah-Nya. Tetapi ada yang sebaliknya memahami sakramen sebagai upacara suci yang mengandung halhal yang tidak bisa dijelaskan. Gereja-gereja Protestan hanya menerima dua sakramen yang ditetapkan oleh Tuhan Yesus Kristus, yaitu Perjamuan Kudus (eucharisti) dan Baptisan. Namun, masih terdapat pandangan transsubstansiasi, kosubstansiasi dan perlambangan tentang makna roti dan anggur yang digunakan dalam perjamuan kudus. Begitu pula dengan pelbagai cara baptisan air dan maknanya masih terus dianut dalam gereja hingga kini. Metode yang digunakan dalam penelitian ini adalah metode penelitian kualitatif. Hasil penelitian menunjukkan bahwa sakramen masih memiliki makna yang sakral bagi gereja. Pemahaman transubstansiasi, kosubstansiasi dan simbolis tentang roti dan anggur dalam perjamuan kudus masih mewarnai anggapan banyak teolog dan pemimpin gereja. Pemahaman serupa terjadi pula bagi baptisan yang oleh sebagian kalangan gereja dianggap hanya sebagai tanda lahiriah (simbol), namun sebagian lainnya memaknainya sebagai unsur yang menyelamatkan.
\end{abstract}

Kata kunci: sakramen, dogmatika, perjamuan kudus, baptisan.

\section{THEOLOGICAL AND DOGMATIC SURVEY ON SACRAMENT IN CHURCH MINISTRY}

\begin{abstract}
The sacrament is a Christian rite established and carried out by the church for centuries. There are various views about the meaning of the sacrament in the church. Some churches regard the sacrament as a visible sign or just an outward sign in which the Lord expresses His grace. However, the other churches understand the sacrament as a sacred ceremony containing things that cannot be explained. The Protestant churches only accept two sacraments established by the Lord Jesus Christ, namely the Eucharist and Baptism. In terms of the understanding on the sacraments, there are transubstantiation, consubstantiation and symbolic views on the meaning of the bread and wine used in the Lord's Supper. Similarly, the churches conduct various ways of water baptism and its meaning is still held in the church today. The approach used in this study is a qualitative research method. The results show that the sacrament still has sacred meanings for the church. The views of transubstantiation, consubstantiation and symbolism about bread and wine in the Holy Communion still characterizes the assumptions of many theologians and church leaders. Regarding the baptism, some churches consider it as an outward sign, and the other churches interpret it as a saving element.
\end{abstract}

Keywords: sacrament, dogmatics, holy communion, baptism.

\section{PENDAHULUAN}

Sakramen memiliki kedudukan yang penting bagi orang Kristen sebagai upacara yang dikaitkan dengan karya keselamatan

Kristus bagi umat-Nya. Kendati demikian pemahaman mengenai sakramen sangat 
beragam. Ada yang melihatnya sebagai upacara suci yang sakral, ada yang memahaminya sebagai sebuah upacara yang sifatnya ilahi dan mistis, tetapi ada pula yang menanggapnya sebagai bagian dari liturgi yang biasa-biasa saja. Pandangan atau anggapan demikian dijumpai secara luas dalam kekristenan.

Berkaitan dengan beragam pemahaman tersebut dapat dilihat pada penjelasan berikut:

In the Christian community sacraments are acts of worship that are understood by the worshipers to give access to an intimate union with the divine and to be efficacious for salvation. The term sacraments is sometimes used in a very broad sense for places, persons, things, ceremonies, and events that mediate, or are intended to mediate, the presence and power of the divine (“Sacrament: Christian Sacraments," n.d.)

Pandangan di atas menunjukkan bahwa umat Kristen melihat sakramen sebagai kegiatan ibadah yang dipahami oleh para penyembah untuk memberi akses kepada suatu kesatuan intim dengan yang ilahi dan manjur bagi keselamatan. Pemahaman demikian mewakili anggapan sebagian orang Kristen secara luas. Unsur sakralitas sakramen mendapat tempat utama dalam pelaksanaannya.

Penting untuk memahami makna sakramen. Yohanes Calvin menekankan:

Sangatlah penting bagi kita bila mengenai sakramen itu diberikan pengajaran yang tegas, supaya kita dapat belajar, apa tujuan diadakannya sakramen-sakramen itu dan bagaimana pemakaiannya sekarang ini (Calvin, 2013, p. 275).

Pendapat Calvin di atas menekankan tentang pentingnya pengajaran bagi kita tentang tujuan sakramen-sakramen dan pemakaiannya sebagai salah satu unsur penting dalam ajaran-ajaran pokok iman Kristen yang dipraktikkan dalam ibadah gerejawi berabad-abad lamanya. Apalagi dewasa ini sakramen-sakramen dalam gereja dilakukan secara berkala dan gradual, terutama perjamuan kudus dengan bermacam-macam pandangan dan pemahaman yang melandasinya.

Oleh sebab itu dalam tulisan ini penulis akan menyoroti sakramen dari sudut pandang teologis, tujuan dan pelaksanaannya dalam gereja. Sakramen sebagai perintah Tuhan Yesus secara langsung kepada murid-murid-Nya untuk dilakukan, telah ditandaskan sebagai dogmatika gereja sejak masa gereja purba. Sakramen juga mendapat tempat yang penting dalam berbagai literatur klasik yang ditulis oleh bapa-bapa gereja. Karena itu beberapa literatur yang digunakan dalam tulisan ini tergolong dalam literatur klasik. Tujuan dari tulisan ini untuk memaparkan betapa pentingnya sakramen sebagai salah satu alat anugerah dalam tradisi iman orang percaya yang memiliki dasar dogmatika yang kuat; bukan hanya sebatas ritus yang dimaknai secara terbatas.

Dalam tulisan ini penulis tidak akan banyak membahasnya dari dimensi praksisnya, yakni dalam bentuk liturginya, sebab corak liturgi sakramen patut diakui sangat beragam dalam isi, bentuk dan variasinya sebagaimana dianut oleh masingmasing denominasi gereja. Meskipun para pakar dogmatika dan teologi sistematika cenderung menggabungkannya dalam pelayanan firman dan sakramen sebagai alat-alat anugerah dalam iman Kristen, namun dalam artikel ini penulis hanya akan membahas tentang sakramen. Sebagai unsur penting dalam dogmatika, yaitu hasil 
penyelidikan orang percaya tentang firman Tuhan yang ditentukan oleh gereja dan diperintahkan untuk dipercayai-dogma berasal dari kata kerja dokein yang artinya menduga, mengira, yang kemudian berarti buah pikiran yang diakui oleh suatu golongan dalam suatu ilmu. Dalam hal ini buah pikiran yang diakui dalam bidang teologi (lihat Soedarmo, 1996, p. 3).

Tinjauan dogmatis terhadap sakramen penting dilakukan untuk membubuhkan dasar pemahaman yang kuat bagi gereja untuk melaksanakannya. Pengertian dogma sendiri menyangkut ketetapan atau perintah dan tafsiran terhadap wahyu ilahi yang berisi doktrin teologi Kristen serta pengakuan iman yang sudah menjadi konsensus universal dalam perkembangan ajaran Kristiani. Dogmatika selanjutnya mencakup segala sesuatu yang dipercaya, dikhotbahkan dan diajarkan kepada jemaat berdasarkan kebenaran firman Tuhan. Hal ini tampak dari definisi berikut:

Dogma is a Greek word that originally meant decree or command, a legally binding opinion or established judgement. Dogma is the church's decreed interpretation of divine revelation. In a general sense, dogma refers to the doctrinal content of Christian theology. In a narrow sense, dogma refers specifically to the few constitutive articles of faith that have defined and approved by near universal consensus throughout the development of Christian thought (Dyrness \& Karkkainen, 2008. p.241).

Karena itu sakramen sebagai salah satu unsur ajaran pokok iman Kristen selain akan ditinjau dari aspek teologis-dogmatis, penulis juga menyoroti pentingnya sakramen berdasarkan Alkitab. Di samping itu pembahasan dalam artikel ini juga akan sedikit menyinggung dasar historis pelaksanaan dan penggunaan sakramen dalam pelayanan gerejawi berabad-abad lampau hingga kini. Oleh karena itu maka judul yang diangkat dalam tulisan ini adalah: "Sakramen Dalam Pelayanan Gerejawi: Sebuah Tinjauan Teologis."

\section{METODOLOGI}

Metode penelitian yang digunakan dalam artikel ini adalah metode kualitatif. Penelitian kualitatif digunakan karena memiliki karakteristik dengan mendeskripsikan suatu keadaan yang sebenarnya, tetapi laporannya bukan sekadar bentuk laporan suatu kejadian tanpa interpretasi ilmiah (Satori \& Komariah, 2011, p. 27)

Berdasarkan pengertian di atas maka kualitas atau hal yang terpenting dalam hal ini adalah sakramen menurut Perjanjian Baru, yang dianut secara luas oleh gerejagereja Protestan. Yang akan diuraikan dalam tulisan ini dengan sendirinya adalah makna dari sakramen secara teologis-dogmatis yang dapat memberikan kontribusi bagi gereja dalam pelaksanaannya. Walaupun demikian laporannya bukan sekadar bentuk laporan suatu kejadian tanpa interpretasi ilmiah sebagaimana lazimnya.

\section{HASIL DAN PEMBAHASAN Pengertian}

Sakramen yang kita gunakan secara luas dalam gereja hingga saat ini memiliki arti yang sakral dalam pengertian dan praktiknya. Menurut Harun Hadiwijono, kata sakramen berasal dari kata sacramentum yang berarti:

Perbuatan atau perkara yang bersifat rahasia, yang kudus, yang dihubungkan dengan para dewa. Di dalam gereja semula 
yang disebut sakramen adalah segala rahasia yang bersangkutan dengan Allah, serta pelayanan-Nya, seperti: upacaraupacara kebaktian dengan segala peralatannya, penyembuhan dan sebagainya (1982, p. 158)

Arti lain dari sakramen yang berasal dari kata Latin sacramentum pada mulanya menunjukkan sejumlah uang yang disimpan oleh dua pihak dalam suatu perjanjian hukum. Setelah ada keputusan pengadilan maka uang dari pihak yang menang dikembalikan, sedangkan uang dari pihak yang kalah disita. Hal ini disebut sacramentum, sebab ia menjadi semacam penghapus salah yang dipersembahakan kepada dewa. Dalam pengertian religius Vulgate memakai kata itu untuk menerjemahkan kata Yunani musterion untuk menunjukkan misteri yang ada dalam agama Yunani (Berkhof, 1997, pp. 124-125). Dalam perkembangan selanjutnya kata itu digunakan oleh gereja untuk menunjuk kepada apa yang diperintahkan oleh Tuhan Yesus Kristus. Bahkan penggunaan kata sakramen dalam gereja dewasa ini berkaitan dengan upacara-upacara yang kudus bagi Tuhan.

Pengertian yang sama dikemukakan oleh R. Soedarmo dalam bukunya Ikhtisar Dogmatika bahwa sakramen atau misterion artinya hal yang tersembunyi atau yang dirahasiakan dan dikuduskan. Kemudian sakramen dipakai juga untuk mengatakan segala sesuatu yang diperbuat dalam perkumpulan ibadat (Soedarmo, 1996, p. 233).

Pemahaman dan pelaksanaan sakramen dalam sejarah pun bermacammacam. Namun demikian misteri yang terkandung dalam sakramen ditafsirkan dari sudut pandang yang berbeda-beda pula. Tetapi agaknya hampir semuanya cenderung mengarah kepada upacara-upacara kudus yang diadakan oleh gereja hingga saat ini. Setiap kali kita mendengar kata sakramen maka pikiran kita tertuju kepada baptisan dan perjamuan kudus di kalangan gereja-gereja Protestan.

\section{Sakramen Sebagai Tanda dan Meterai}

Secara dogmatis para teolog sepakat bahwa sakramen adalah tanda dan meterai bagi orang percaya, sebagaimana yang didefiniskan oleh Louis Berkhof, bahwa:

\begin{abstract}
Sakramen adalah peraturan kudus yang ditetapkan oleh Kristus, di mana tandatanda yang bisa dilihat dan dirasa dari anugerah Allah di dalam Kristus, dan keuntungan dari perjanjian anugerah dilambangkan, dimeteraikan, dan diterapkan untuk orang percaya, dan pada gilirannya menyatakan iman dan kesetiaan mereka kepada Tuhan (1997, p. 125).
\end{abstract}

Menurut pengertian di atas maka yang dimaksud dengan sakramen adalah peraturan yang ditetapkan oleh Kristus, yang dilambangkan dan dimeteraikan agar orang percaya beriman dan setia kepada Tuhan.

Atau dengan kata lain, sakramen adalah tanda dan meterai yang kelihatan dan suci untuk menjelaskan segala sesuatu yang dijanjikan-Nya. Tanda dan meterai yang meneguhkan iman (Soedarmo, 1996, p. 234). Tanda-tanda yang kelihatan berarti upacara suci yang dilakukan oleh gereja di mana jemaat melihat, menyaksikan dan mengalaminya.

Menurut Calvin sakramen itu adalah suatu tanda lahiriah yang dipakai Allah untuk memeteraikan dalam batin kita janji-janji akan kerelaan-Nya terhadap kita, supaya iman kita yang lemah diteguhkan, dan supaya kita pun 
menyatakan kasih dan kesetiaan kita kepadaNya, baik di hadapan Dia sendiri dan malaikat-malaikat-Nya, maupun di hadapan manusia (Calvin, 2013). Tanda-tanda lahiriah berupa pelaksanaan sakramen yang menuntun kepada keteguhan iman dan kesetiaan orang percaya.

Kebanyakan penggunaan istilah sakramen merujuk kepada jumlah yang terbatas dari ritual kuno yang dipahami sebagai perbuatan Yesus Kristus yang dilanjutkan oleh gereja. Karena itu gerejagereja Prostestan biasanya membatasi jumlah sakramen menjadi dua, yaitu baptisan dan perjamuan kudus sebagaimana dijumpai dalam Perjanjian Baru ("Sacrament: Christian Sacraments," n.d.).

Pandangan tersebut mengandung pengertian bahwa sakramen dalam Perjanjian Baru merupakan ketetapan Tuhan Yesus sendiri, yang disampaikan kepada muridmurid-Nya pada perjamuan malam hingga sesaat sebelum la terangkat ke surga. Dalam hubungan tersebut R. Soedarmo menegaskan bahwa:

Sakramen ditentukan oleh Tuhan sendiri, dan jumlahnya tidak lebih dari dua. Orang dapat mengatakan hal-hal yang suci atau yang gaib, tetapi Tuhan hanya memberi dua sakramen saja, yaitu Perjamuan Kudus dan Baptis Suci (Mat. 28:19; 26: 26-28; 1 Kor. 11:23-26). Jadi dalam sakramen kita harus membedakan dua hal: a) tanda: air. Roti dan anggur; b) yang ditandai: segala sesuatu yang dijanjikan oleh Tuhan Yesus ialah persekutuan dengan Tuhan Yesus; berarti bahwa setiap orang yang menerima tanda-tanda itu dengan kepercayaan, ia turut Tuhan Yesus di dalam kesengsaraan dan kematian-Nya. Akan tetapi juga ia turut dibangkitkan pula dari kematian, dan masuk ke dalam dunia baru yang mulia dan kekal (Soedarmo, 1996, p. 235).
Pengegasan tersebut mengingatkan kepada kita bahwa sakramen bukan sekadar ritus tertentu dalam gereja, tetapi sesungguhnya ia adalah perintah Allah yang harus dilakukan oleh orang percaya.

Sebelum Tuhan Yesus naik ke surga la memerintahkan kepada para rasul: "Karena itu pergilah, jadikanlah semua bangsa muridKu dan baptislah mereka dalam nama Bapa dan Anak dan Roh Kudus, dan ajarlah mereka melakukan segala sesuatu yang Kuperintahkan kepadamu" (Mat. 28:19-20). Pada malam hari sebelum Tuhan Yesus disalibkan, yaitu pada perjamuan Paskah, setelah la memecah-mecahkan roti dan memberikan kepada para murid, dan berkata: "Perbuatlah ini menjadi peringatan akan Aku" (Luk. 22:19). Dari sini jelas bahwa baptisan kudus dan perjamuan kudus bukan hasil penemuan manusia, melainkan penetapan Allah sendiri. Allah berkenan menghubungkan sakramen kudus dengan sengsara dan kematian Tuhan Yesus yang mendatangkan keselamatan, atau berkenan menghubungkannya dengan perjanjian-Nya yang telah dibaharui dalam Kristus. Oleh karena itu sakramen tidak boleh dipisahkan dari karya penyelamatan Kristus yang dilakukan di Golgota. Sebab Kristus adalah pemenuhan sakramen, sedangkan sakramen adalah tanda dan meterai karya penyelamatan Kristus, yang mendamaikan Allah dan manusia (Hadiwijono, 1982, pp. 161-162).

Selanjutnya penulis akan menguraikan sakramen sebagai tanda dan meterai dari sudut pandang dogmatika sebagai berikut:

\section{Sebagai tanda}

Sakramen sebagai tanda, dapat diringkaskan dari uraian Berkhof sebagai berikut: (1) tanda yang kelihatan (visible sign) di mana setiap sakramen berisi elemen 
material yang dapat dilihat secara inderawi. Sakramen bukan saja mencakup elemen yang dipakai seperti air, roti dan anggur tetapi juga ritual yang dilakukan melalui elemenelemen ini (Kej. 9:12-13; Rm. 4:11); (2) anugerah spiritual dalam hati yang dilambangkan atau dimeteraikan yang biasa disebut materia internal. Hal ini dinyatakan dalam Alkitab sebagai perjanjian anugerah, kebenaran iman, pengampunan dosa, persekutuan dengan Kristus dalam kematian dan kebangkitan-Nya, terkait dengan Kristus dan semua kekayaan rohaninya (Rm. 6:3); (3) persekutuan sakramental antara lambang dan yang dilambangkan (forma sacramenti): tidak bersifat fisik, lokal, seolah-olah tanda dan lambang itu hadir pada tempat yang sama, di mana orang percaya dan yang tidak percaya menerima sakramen yang penuh ketika menerima lambang itu. Melainkan bersifat spiritual di mana sakramen diterima dalam iman, anugerah Allah menyertainya. Lambang eksternal dipakai Roh Kudus sebagai pencurahan berkat ilahi (Berkhof, 1997, pp. 126-127).

Unsur-unsur yang berkaitan erat dengan sakramen sebagai tanda mendapat penekanan kuat pada perjanjian anugerah, kebenaran iman, pengampunan dosa, persekutuan dengan Kristus dalam kematian dan kebangkitan-Nya, pula berkaitan erat dengan Kristus dan semua kekayaan rohaninya. Tanda sebagai perlambangan karya Kristus dan berkat rohani yang menyertai merupakan misteri atau rahasia dalam sakramen seperti yang sudah banyak disinggung sebelumnya.

Jadi yang digambarkan dalam sakramen adalah janji-janji Allah yang ada dalam Injil, yaitu bahwa karena korban Kristus di kayu salib, orang beriman mendapat pengampunan dosa dan hidup yang kekal (Hadiwijono, 1982, p. 160). Inilah kekayaan atau berkat rohani yang terkandung dalam sakramen sebagai tanda.

Secara tersirat kita dapat menyimak dalam pengajaran Tuhan Yesus jauh sebelum la memerintahkan pelaksanaan sakramen dalam perjamuan malam sesaat sebelum la ditangkap. Ketika orang-orang Yahudi meminta tanda kepada-Nya agar mereka percaya, maka Tuhan Yesus memproklamirkan diri-Nya sebagai roti hidup yang turun dari sorga (Yoh. 7:30-41). Secara khusus la menekankan bahwa mereka yang tidak makan tubuh-Nya dan tidak minum darahNya mereka tidak mempunyai hidup, sedangkan mereka yang makan tubuh-Nya dan minum darah-Nya mempunyai hidup kekal dan akan dibangkitkan pada akhir zaman (Yoh. 6:53-58). Boleh dikatakan bahwa inilah penekanan pendahuluan tentang sakramen perjamuan kudus sebagai tanda keselamatan bagi orang percaya.

Tampaknya bahwa tanda yang ditekankan Tuhan Yesus bukan semata-mata tanda lahiriah, tetapi tubuh dan darah-Nya memberi hidup yang kekal; tanda yang memenuhi hati, jiwa dan pikiran kita.

\section{Sebagai Meterai}

Para teolog tampaknya sepakat bahwa sakramen selain sebagai tanda, juga sebagai meterai bagi orang percaya. Sakramen sebagai meterai atau cap berfungsi untuk mengokohkan kepercayaan kepada janji-janji Allah. Karena itu menurut Soedarmo meterai berdasarkan Roma 4:11: "Dan tanda sunat itu diterimanya [Abraham] sebagai meterai kebenaran berdasarkan iman yang ditunjukkannya, sebelum ia bersunat. Demikianlah ia dapat menjadi bapa semua orang percaya yang tak bersunat, supaya kebenaran diperhitungkan kepada mereka." Meterai atau cap yang dikenakan kepada orang percaya melalui sakramen, juga 
dikukuhkan dengan meterai oleh Roh Kudus ketika kita percaya (Ef. 1:13).

Karena Sakramen sebagai tanda dan sarana keselamatan, maka menerima dan memahami sakramen hendaknya ditempatkan dalam kerangka iman dan didasarkan kepada iman. Sakramen biasanya diungkapkan dengan kata-kata dan tindakan. Maka sakramen dalam Gereja Katolik mengandung 2 (dua) unsur hakiki yaitu: forma, artinya kata-kata yang menjelaskan peristiwa ilahi dan materia yang artinya barang atau tindakan tertentu yang kelihatan.

Dengan begitu maka sakramen yang diperintahkan Tuhan untuk dilakukan menunjukkan aspek yuridis, yang dapat dipercaya kebenarannya bagi orang percaya yang menerima sakramen.

\section{Landasan Historis}

Pada mulanya yang disebut sakramen adalah segala rahasia yang bersangkutan dengan Allah serta pelayanan-Nya, seperti: upacara-upacara kebaktian dengan segala peralatannya, penyembuhan, dan sebagainya. Pada abad pertengahan gereja mulai membatasi secara tegas pengertian sakramen.

Menurut Dieter Becker, dalam gereja purba kata sacramentum atau musterion dimaksudkan hubungan di antara salah satu kadar Kristen dengan suatu perbuatan, tanda atau rumusan yang dianggap mengandung rahasia (1996, p. 155). Sakramen sebagai salah satu kadar atau ukuran mengandung pengertian bahwa sakramen merupakan ukuran untuk menentukan norma berdasarkan iman.

Selanjutnya ditandaskan bahwa istilah sacramentum sudah dipakai bagi baptisan dan ekaristi oleh Tertulianus. Baptisan anakanak dapat dibuktikan pertama kali dalam tulisan Irenius. Gagasan korban misa, yaitu dalam Perjamuan Kudus korban salib Kristus dipersembahkan kembali oleh para imam, pertama sekali ditemukan dalam tulisan Cyprianus. Sedangkan Agustinus menyebut sakramen sebagai Firman yang kelihatan (visible verbum). Yohanes Damasceny, Ignatius dari Antiokhia menyebut Perjamuan Kudus sebagai "obat keabadian" (farmakonathanasias). Pada abad pertengahan, yaitu dalam Konsili Lateran ke4 (1215) pandangan bahwa roti dan anggur betul-betul tubuh Tuhan dan darah Kristus (transsubstansiasi) dikokohkan. Selanjutnya dalam konsili Florens (1439) Petrus Lambardus mempertahankan tujuh sakramen, yaitu: baptisan (baptismus), peneguhan (confirmatio), Perjamuan Kudus (ekaristia), pertobatan (poenitentia), pengurapan terakhir (extremaunctio), penahbisan Imam (ordo) dan perkawinan (matrimonium) (Becker, 1996, p. 155). Ketujuh sakramen ini tidak akan diuraikan lebih jauh dalam tulisan ini.

Gereja-gereja Reformasi atau Protestan menetapkan hanya dua sakramen, yaitu baptisan dan perjamuan kudus (ekaristi). Ketetapan ini berdasarkan keyakinan bahwa sakramen bukanlah hasil penemuan manusia, melainkan penetapan Allah sendiri. Allah berkenan menghubungkan sakramen kudus dengan sengsara dan kematian serta kebangkitan Tuhan Yesus yang mendatangkan keselamatan, atau berkenan menghubungkannya dengan perjanjian-Nya yang telah diperbaharui di dalam Kristus (Hadiwijono, 1982, p. 162).

Suatu pandangan dasar disingkapkan dalam kata Yunani yang biasa dipakai untuk suatu sakramen, mysterion. Perjanjian Baru menggunakan istilah itu yang merujuk kepada pemikiran-pemikiran rahasia Allah yang 
melampaui segala akal yang harus disingkapkan kepada orang-orang yang kepadanya Allah ingin rahasia itu disingkapkan (Mrk. 4:11). Sayangnya kata Latin sacramentum yang dipilih oleh Tertulianus untuk menggantikan mysterion tidak memiliki kedalaman yang sangat kaya seperti mysterion. Sacramentum adalah istilah yang merujuk kepada sumpah setia seorang prajurit untuk memelihara janji. Sedangkan mysterion mengandung makna yang lebih dalam dan luas. Agustinus mendefinisikan sakramen sebagai tanda kudus yang merepresentasikan apa yang ditandakannya seperti roti dan anggur sebagai tubuh dan darah (White, 2017, pp. 172-174).

Misteri atau rahasia yang terkandung dalam baptisan dan perjamuan kudus pada mulanya menyangkut cara yang digunakan dalam pelaksanaannya. Setelah semua orang yang belum dibaptis keluar maka pintu dikunci. Sebab apa yang akan terjadi merupakan rahasia. Perayaan sakramen utama, yaitu ekaristi di lakukan sehingga orang-orang di luar jemaat tidak boleh mengetahuinya (White, 2017, p. 61).

Cara demikian dipakai untuk mempertahankan makna harafiah dari kata musterion atau rahasia, meskipun yang dimaksudkan adalah janji-janji Allah sebagaimana telah diutarakan sebelumnya. Namun demikian sebenarnya rahasia atau misteri dalam pelaksanaan sakramen, khususnya perjamuan Tuhan erat kaitannya dengan sikap hati serta iman orang yang menerima sakramen itu. Karena itu tiap-tiap orang hendaknya menguji dirinya sebelum makan roti dan minum dari cawan Tuhan. Banyak di antara mereka yang mengalami hukuman, sakit hingga meninggal karena tidak mengakui tubuh Tuhan sebagaimana peringatan Paulus dalam 1 Kor. 11: 27-32.
Misteri atau rahasia yang terkandung dalam sakramen khususnya dihubungkan dengan elevasi elemen-elemen eukaristi. Menurut J.L. Ch. Abineno, dalam abad-abad pertama perjamuan malam dianggap sebagai misterium, sebagai rahasia Allah yang tersembunyi di balik elemen-elemen yang nampak. Rahasia itu tidak boleh diterangkan, tetapi harus diterima dan dipercayai sebagai suatu kebenaran (Abineno, 1966, p. 9). Meskipun ada pakar yang melihat hal ini sebagai suatu kesatuan yang bersifat mistis, tetapi pada mulanya unsur kekudusan yang melingkupi sakramen ditanggapi dengan makna rahasia yang terkandung di dalamnya, tanpa jemaat harus mengerti maksud sebenarnya.

Apa yang diutarakan di atas mengandung makna rohani tentang persekutuan dalam kematian dan kebangkitan Tuhan melalui Perjamuan Kudus. Penegasan yang sama ditegaskan terhadap baptisan sebagai wujud persekutuan dengan Tuhan dalam kematian dan kebangkitan-Nya untuk menerima hidup yang baru. Sebagaimana dituliskan oleh Paulus:

\begin{abstract}
Atau tidak tahukah kamu, bahwa kita semua yang telah dibaptis dalam Kristus, telah dibaptis dalam kematian-Nya? Dengan demikian kita telah dikuburkan bersamasama dengan Dia oleh baptisan dalam kematian, supaya, sama seperti Kristus telah dibangkitkan dari antara orang mati oleh kemuliaan Bapa, demikian juga kita akan hidup dalam hidup yang baru" (Rm. 6 : 3-4).
\end{abstract}

Lebih jauh James F. White menandaskan bahwa gereja meneruskan untuk mengulang tindakan-tindakan Yesus mulai saat peristiwa kematian-Nya, jauh sebelum Kitab Suci dituangkan dalam bentuk 
tertulis. Apa yang kita temukan tercatat dalam Kitab Suci merepresentasikan praktikpraktik sakramental yang telah lama diselenggarakan gereja. Pelbagai cerita tentang penetapan Perjamuan malam oleh Yesus (institution narratives) (Mat. 26:26-29; Mrk. 14:22-25; Luk. 22:15-20) dapat berbicara kepada kita tentang pemenuhan kehendak Tuhan itu oleh gereja-gereja di berbagai tempat sebagaimana mereka melaksanakan pengarahan-pengarahan Tuhan mereka sendiri (White, 2017, pp. 190191).

Sakramen baptisan dan perjamuan kudus memiliki landasan alkitabiah yang kuat. Tuhan Yesuslah yang secara langsung menetapkan baptisan dan perjamuan kudus di mana gereja bertindak sebagai pelaksananya. Pengertian yang memuaskan tentang sakramen-sakramen harus dimulai dengan kepercayaan bahwa Allah bertindak dalam sakramen, mengambil inisiatif dalam sakramen (Hadiwijono, 1982, pp. 161-162).

Meskipun sakramen-sakramen yang dianut oleh gereja-gereja Reformasi itu sebenarnya berakar dalam tradisi Yudaisme, yaitu pesach (paskah) dan sunat, tetapi Yesus mengamanatkan kepada murid-murid untuk melakukannya sebagai pemilik otoritas dalam Perjanjian Baru. Ini mengandung pengertian bahwa sakramen-sakramen dalam Perjanjian baru dimulai oleh Yesus Kristus dan berpusat pada diri-Nya sebagai intisari sakramen. Pula Karena itu maka gereja-gereja Reformasi hanya melaksanakan dua sakramen, yaitu baptisan dan perjamuan kudus sebagaimana diperintahkan oleh Tuhan Yesus. Tuhan Yesus sendiri memberi teladan dengan memberi diri-Nya dibaptis oleh Yohanes Pembaptis.

Pada umumnya gereja-gereja Protestan hanya menganut dua sakramen seperti yang diperkenalkan dalam Perjanjian Baru, yaitu Baptisan dan Perjamuan Kudus. Menurut Berkhof, Gereja Perjanjian Baru memiliki dua sakramen yaitu baptisan dan perjamuan kudus sebab kedua sakramen itu merupakan sakramen tanpa darah, tetapi keduanya melambangkan berkat spiritual yang sama, sebagaimana yang dilambangkan oleh sunat dan paskah (Berkhof, 1997, p. 131). Alasan utama pengakuan terhadap hanya dua sakramen oleh gereja-gereja Protestan karena diperintahkan langsung oleh Tuhan Yesus (Mat. 26:26-28; 28:19-20), kemudian diteruskan oleh para Rasul (1 Kor. 11:23-26), kemudian diterima secara luas hingga saat ini.

\section{Baptisan}

Baptisan adalah sakramen yang diperintahkan sendiri oleh Tuhan Yesus. Terminologi yang digunakan dalam Perjanjian Baru bersifat umum. Kata kerja baptisein dan kata benda baptismoi muncul dalam Markus 7:4 yang berasal dari pencucian Yahudi. Dalam Ibrani 6:2 kata benda jamak baptismoi termasuk baptisan kristiani digunakan oleh kelompok agama lain; baik Yahudi maupun agama-agama lain, yang secara implisit kontras dengan baptisan yang digunakan dalam kekristenan. Sebagaimana baptisma berbeda dengan baptismoi, merefleksikan secara khusus penggunaan tebilah dalam baptisan kaum proselit dalam Markus 10:38, Lukas 12:50, sebagaimana terjadi dalam Injil dan Kisah Para Rasul yang secara eksklusif mengacu kepada baptisan Yohanes (Beasley-Murray, 1973, p. 29).

Baptisan menurut Calvin adalah tanda bahwa kita diterima masuk ke dalam persekutuan gereja, supaya kita ditanamkan di dalam Kristus, kita terhisab sebagai anakanak Allah. Baptisan itu diberikan Allah 
kepada kita dengan tujuan yang sama untuk semua sakramen: yaitu pertama untuk membantu iman kita dalam hubungan dengan Dia, selanjutnya untuk membantu pengakuan iman kita dalam hubungan dengan manusia (Calvin, 2013, p. 281).

Dalam pelaksanaannya, baptisan oleh sementara gereja dianggap sebagai syarat penerimaan menjadi anggota gereja, khususnya bagi gereja-gereja yang menganut baptisan orang dewasa. Orang-orang yang telah menyatakan iman percayanya kepada Tuhan Yesus Kristus kemudian dibimbing dan diberi pengajaran tentang dasar-dasar iman Kristen sebelum dibaptis.

Adapun beberapa makna baptisan yang umum dipegang oleh gereja adalah sebagai berikut (Sinaga, 2018, p. 71):

1. Menyatakan iman dan pertobatan.

2. Satu dalam kematian dan kebangkitan Kristus.

3. Memiliki hidup baru.

4. Tubuh yang berdosa ditanggalkan.

5. Tanda kerelaan untuk taat kepada perintah Tuhan Yesus.

\section{Perjamuan Kudus}

Ekaristi adalah struktur paling khas ibadah Kristen. Ekaristi (pengucapan syukur) atau perjamuan malam Tuhan (1 Kor. 11:20), pemecahan roti (Kis. 2:46; 20:7), liturgi ilahi, misa, perjamuan kudus, korban kudus dan peringatan akan Tuhan. Terkadang ekaristi disebut: misa orang percaya, persembahan korban, persembahan. Istilah ini sejak abad pertama telah digunakan sebagai istilah yang paling deskriptif (White, 2017, p. 227).

Kata rahasia (musterion) yang melekat dalam perjamuan kudus oleh bapa-bapa gereja dikaitkan dengan substansinya, yaitu roti dan anggur. Ada yang menganggap roti dan anggur adalah benar-benar tubuh dan darah Tuhan, tetapi ada pula yang menafsirkannya sebagai perlambangan saja. Hal ini didasarkan pada ucapan Tuhan Yesus dalam Matius 26:26-28.

Ignatius dari Antiokhia mendasarkan kesimpulannya berdasarkan Yoh. 6:54-58 tentang perjamuan kudus sebagai obat keabadian. Dengan memakan dan meminumnya kita menjadi pewaris hidup kekal. Agustinus mengatakan bahwa substansi itu tidak berubah, meskipun di sisi lain ia membedakan antara lambang dan yang dilambangkan. Beberapa teolog abad pertengahan sependapat dengan Agustinus bahwa substansi itu simbolis tetapi tetap tidak berubah. Inilah yang diartikan sebagai transubstansiasi, yaitu pandangan bahwa roti dan anggur dalam perjamuan Tuhan adalah benar-benar menjadi tubuh dan darah Kristus ("Transubtansiasi dan Konsubstansiasi adalah Tidak Alkitabiah," 2009).

Luther menolak doktrin transubstansiasi dan menggantinya dengan doktrin kosubstansiasi, yaitu bahwa roti dan anggur tetaplah sama, tetapi dalam Perjamuan Kudus ada suatu kehadiran nyata yang ajaib dan misterius dari keseluruhan pribadi Kristus, baik tubuh maupun darah di dalam, di bawah, dan bersamaan dengan elemenelemen itu. Kristus secara fisik hadir dalam Perjamuan Kudus, sehingga mereka yang makan dan minum tubuh dan darah Tuhan dengan mulut jasmani (manducatiooralis) dan bukan hanya secara iman (Berkhof, 1997, p. 190).

Luther berpendapat bahwa tiap-tiap tabiat Kristus saling meresap dan kemanusiaan-Nya berpartisipasi dalam sifatsifat keliahian-Nya. Jika Allah maha hadir, maka tubuh dan darah-Nya juga hadir di mana-mana dan mungkin dalam sakramen. la ingin supaya perkataan Kristus diterima secara harfiah, meskipun ia menolak bahwa 
terjadi perubahan dalam unsur-unsur itu ("Transubtansiasi dan Konsubstansiasi adalah Tidak Alkitabiah," 2009).

Lebih jauh Calvin mengatakan bahwa para Reformator semuanya menolak teori pengorbanan dari perjamuan kudus, serta doktrin abad pertengahan tentang transubstansiasi, tetapi berbeda dalam penyusunan doktrin menurut Alkitab tentang perjamuan kudus. Dalam pandangan Calvin roti dan anggur adalah lambang-lambang yang diberikan Kristus kepada kita, yaitu tubuh dan darah-Nya. Tujuannya supaya kita bersatu dengan Dia, dan memperoleh substansi-Nya dan akan merasakan kekuatan dan persekutuan dengan semua harta-Nya (Calvin, 2013, p. 303).

Pandangan tentang makna tubuh dan darah Tuhan sebagaimana paparan di atas masih terdapat dalam gereja hingga saat ini.

\section{Analisis}

Patut diakui bahwa sakramen yang dikenal dan dianut dalam berbagai aliran atau denominasi gereja Reformasi hingga saat ini diangap sebagai upacara kudus dibandingkan dengan ibadah Minggu pada umumnya. Tradisi yang dipertahankan dalam gereja-gereja Prostestan, khususnya menyangkut perjamuan kudus yang dianggap sakral, jemaat yang mengikutinya hanyalah mereka yang telah dibaptis dan mengikuti sidi. Persiapan untuk mengikuti sakramen itu diwartakan sebelum pelaksanaannya, sehingga jemaat yang tidak mengikuti persiapan tidak diizinkan mengikuti sakramen ini. Selain dianggap sakral, juga terindikasi pemahaman mengenai misteri yang terkandung dalam perjamuan kudus adakalanya dikaitkan dengan keyakinan yang sifatnya mistis dalam nuansa yang bersifat negatif. Terutama yang berkaitan dengan peringatan dalam 1 Korintus 11:27-30:
Jadi barangsiapa dengan cara yang tidak layak makan roti dan minum cawan Tuhan, ia berdosa terhadap tubuh dan darah Tuhan. Karena itu hendaknya tiap-tiap orang menguji dirinya sendiri dan baru sesudah itu makan roti dan minum dari cawan itu. Karena barangsiapa makan dan minum tanpa mengakui tubuh Tuhan, ia mendatangkan hukuman atas dirinya. Sebab itu banyak di antara kamu yang lemah dan sakit, dan tidak sedikit yang meninggal.

Ayat-ayat ini dipahami secara mistis, bahwa jika seseorang tidak mempersiapkan diri ia akan menerima hukuman, bahkan kematian bila mengikuti perjamuan kudus. Biasanya dikaitkan dengan dosa yang belum dibereskan. Inilah yang menjadi alasan Luther menambahkan sakramen pengakuan dosa, yang kemungkinan merupakan warisan gereja Katolik Roma, atau penafsiran terhadap Markus 16:16; 1 Korintus 10:1-5 yang sebenarnya konteksnya berbeda.

Sedangkan terhadap sakramen baptisan kudus, dilakukan bagi orang yang sudah bertobat dan mengakui dosa-dosanya, terutama dalam baptisan orang dewasa. Bagi pembaptisan anak-anak, orang tuanyalah yang bertanggung jawab bagi pembinaan iman anak-anak yang dibaptis. Orang tua yang sedang dalam disiplin gereja karena satu dan hal lain, maka anak-anaknya untuk sementara waktu tak dapat menerima sakramen baptisan kudus.

Gereja-gereja Reformasi atau Protestan di Indonesia tampaknya memegang teguh dogmatika tentang sakramen dengan hanya menerima dan melaksanakan dua sakramen, yaitu, baptisan dan perjamuan kudus. Meskipun gereja Lutheran sebenarnya mengenal tiga sakramen yang ditentukan oleh Kristus, yaitu: 
baptisan, perjamuan kudus dan pengakuan dosa (Becker, 1996, p. 155). Yang berbeda hanya tata cara pelaksanaannya.

Dalam tata ibadah yang disusun oleh Calvin di Strasburg yang masih banyak dipakai di Indonesia, Sakramen Perjamuan Kudus dirayakan setiap dua minggu; la memperkenalkan sistem pemerintahan presbiterial dalam gereja; tetapi tidak kompromi dengan ajaran Katolik.

Dalam pelaksanaannya sakramen baptisan diberikan kepada seseorang yang telah percaya sekali seumur hidupnya, kecuali dalam doktrin anabaptis-Anabaptis (bahasa Yunani: $\quad \alpha v \alpha \quad \beta \alpha \pi \pi \zeta \zeta \omega$-dibaptis kembali) yaitu orang Kristen yang termasuk jenis Reformasi Radikal. Mereka tidak memiliki suatu organisasi yang resmi dan memiliki berbagai-bagai variasi. Baptisan orang percaya yaitu salah satu ciri utama kepercayaan kaum Anabaptis, dan mereka menolak baptisan untuk anak bayi oleh orang tua mereka ("Anabaptis," 2019)—yang melakukan pembatisan ulang. Sedangkan Ekaristi atau perjamuan kudus dilakukan secara gradual menurut doktrin setiap gereja.

Menurut Th. Van den End corak gereja Belanda banyak dianut di Indonesia. Penyimpangan yang paling besar artinya terdapat dalam pelayanan sakramen Perjamuan Kudus. Menurut gereja di Belanda setiap orang yang masuk Kristen dan dibaptis pada umur dewasa sekaligus melakukan sidi dan wajiblah mengikuti perjamuan. Tata gereja tahun 1643 menetapkan bahwa orang Indonesia yang masuk Kristen tidak boleh mengikuti sakramen perjamuan kudus, barulah boleh merayakan perjamuan kudus apabila ia sendiri menyatakan niatnya dan mengikuti pelajaran agama terlebih dahulu. Pembaptisan dipisahkan dari perjamuan kudus. Yang berhak melayani Perjamuan Kudus hanyalah pendeta dan imam (End,
1985, p. 120). Yang dimaksudkan di sini adalah bahwa perjamuan kudus dan baptisan tidak dipersiapkan melalui pengajaran atau katekisasi terlebih dahulu. Ada kecenderungan bahwa setiap orang yang telah mengaku percaya langsung menerima sakramen baptisan tanpa katekisasi terlebih dahulu.

Kendati demikian dalam perkembangannya setiap gereja memiliki aturan tentang pelaksanaan baptisan dan perjamuan kudus. Bagi gereja-gereja Protestan yang menganut pembaptisan anakanak, pengajaran dan bimbingan diberikan kepada orang tua yang akan membaptis anaknya-Calvin dan kebanyakan teolog Protestan mengaitkan baptisan anak-anak dengan janji Tuhan kepada Abraham tentang sunat sebagai suatu tanda perjanjian kepada keturunannya. Anak-anak juga termasuk dalam perjanjian Allah yang berhak menerima keselamatan (Kis. 2:38-39). Itu sebabnya dalam banyak literatur dogmatika, sakramen baptisan dalam Perjanjian Baru selalu disejajarkan dengan sunat dalam Perjanjian Lama. Namun pengajaran tentang dasar iman Kristen diwajibkan bagi mereka yang akan mengikuti perjamuan kudus dengan kurun waktu tertentu yang ditentukan oleh gereja. Sedangkan gereja-gereja beraliran Injili, Pentakosta dan Karismatik menganut baptisan orang dewasa, yaitu bahwa orang yang dibaptis haruslah terlebih dahulu dijadikan murid atau diberi pengajaran; atau bagi mereka yang telah percaya (Mat. 28:19; Mrk. 16:16). Perbedaan-perbedaan tersebut belum termasuk tata cara pelaksanaannya, tetapi paling tidak kenyataan ini menggambarkan ciri khas atau doktrin masing-masing gereja. Namun yang terpenting adalah pengakuan dan pelaksanaan dua sakramen yang telah ditetapkan oleh Tuhan Yesus sendiri. 
Hasil kajian menunjukkan bahwa sakramen masih memiliki makna yang sakral bagi gereja. Pemahaman transubstansiasi, kosubstansiasi dan simbolis tentang roti dan anggur dalam perjamuan kudus masih mewarnai anggapan banyak teolog dan pemimpin gereja. Pemahaman serupa terjadi pula bagi baptisan yang oleh sebagian kalangan gereja dianggap hanya sebagai tanda lahiriah (simbol), namun sebagian lainnya memaknainya sebagai unsur yang menyelamatkan.

\section{KESIMPULAN}

Berdasarkan uraian di atas, tampak bahwa sakramen baptisan dan perjamuan kudus merupakan misteri atau rahasia yang diperintahkan oleh Tuhan Yesus untuk dilakukan. Gereja kemudian menegaskannya sebagai dogmatika atau doktrin dasar iman Kristen, dan ditetapkan untuk dilaksanakan. Para pakar mengartikan sakramen sebagai tanda dan materai yang diberikan Tuhan kepada gereja untuk dilaksanakan. Gereja-

\section{DAFTAR RUJUKAN}

Abineno, J. L. Ch. (1966). Ibadah Jemaat Dalam Abad-Abad Pertengahan. Jakarta: BPK Gunung Mulia.

Anabaptis. (2019). In Wikipedia: Ensiklopedia Bebas. Retrieved from https://id.wikipedia.org/w/index.php?titl $\mathrm{e}=$ Anabaptis\&oldid $=16200334$

Beasley-Murray, G. R. (1973). Baptism in the New Testament. Grand Rapids: Eerdmans.

Becker, D. (1996). Pedoman Dogmatika. Jakarta: BPK Gunung Mulia.

Berkhof, L. (1997). Teologi Sistematika 5: Doktrin Gereja. Jakarta: Lembaga Reformed Indonesia. gereja Reformasi menetapkan dua sakramen kudus, yaitu baptisan dan perjamuan kudus. Dua sakramen tersebut berakar dari Perjanjian Lama, yang sejajar dengan sunat dan paskah (pesach). Itu sebabnya sakramen mendapat tempat yang sentral dalam dogmatika Kristen. Meskipun terjadi perbedaan sana sini dalam pelaksanaannya, tetapi kedua sakramen ini masih dipegang teguh sebagai warisan iman bagi gereja dan orang percaya sampai saat ini. Kebanyakan gereja Reformasi meyakini sakramen sebagai simbol atau tanda bagi orang percaya dalam persekutuan mereka dengan Kristus Yesus, Sang Juruselamat dan kepala gereja.

Tulisan ini hanya memaparkan sebagian kecil dari pembahasan yang begitu luas tentang sakramen oleh para pakar. Namun setidaknya tulisan ini dapat memberikan sedikit gambaran teologisdogmatis tentang sakramen yang dianut, dipercaya sejak berabad-abad yang lampau dan dipraktikkan oleh gereja hingga saat ini.

Calvin, Y. (2013). Institutio: Pengajaran Agama Kristen. Jakarta: BPK Gunung Mulia.

Dyrness, William A. \& Veli-Matti Karkkainen. (2008). Global Dictionary of Theology. USA: InterVarsity Christian Fellowship.

End, Th. V. den. (1985). Ragi Carita Sejarah Gereja. Jakarta: BPK Gunung Mulia.

Hadiwijono, H. (1982). Inilah Sahadatku. Jakarta: BPK Gunung Mulia.

Sacrament: Christian Sacraments. (n.d.). Retrieved June 15, 2019, from https://www.encyclopedia.com/environ ment/encyclopedias-almanacstranscripts-and-maps/sacramentchristian-sacraments 
Satori, D., \& Komariah, A. (2011). Metodologi Penelitian Kualitatif. Bandung: Alfabeta.

Sinaga, E.D. (2018). "Doktrin Alkitab Tentang Baptisan: Suatu Kajian Teologis Tentang Praktek Upacara Baptisan di Gereja Masehi Advent Hari Ketujuh." Jurnal IImiah Teologi 6 (2): 66-93.

Soedarmo, R. (1996). Ikhtisar Dogmatika. Jakarta: BPK Gunung Mulia.

Transubtansiasi dan Konsubstansiasi adalah Tidak Alkitabiah. (2009). Retrieved
August 31, 2019, from Kupas Tuntas KATOLIK website: https://chatolic.wordpress.com/2009/08 /27/transubtansiasi-dankonsubstansiasi-adalah-tidakalkitabiah/

White, J. F. (2017). Pengantar Ibadah Kristen. Jakarta: BPK Gunung Mulia. 